\title{
Enhanced Receptor Modeling Using Expanded Equations with Parametric Variables for Secondary Components of $\mathrm{PM}_{2.5}$
}

\author{
Ho-Tang Liao ${ }^{1,2}$, Ming-Tung Chuang ${ }^{1}$, Ping-Wen Tsai ${ }^{1}$, Charles C.-K. Chou ${ }^{1 *}$, \\ Chang-Fu $\mathrm{Wu}^{2,3^{*}}$
}

${ }^{1}$ Research Center for Environmental Changes, Academia Sinica, Taipei 11529, Taiwan

${ }^{2}$ Institute of Environmental and Occupational Health Sciences, National Taiwan University, Taipei 10055, Taiwan

${ }^{3}$ Department of Public Health, National Taiwan University, Taipei 10055, Taiwan

\begin{abstract}
Receptor modeling provides valuable information to help develop effective control strategies. Additionally, incorporating parametric variables into expanded receptor modeling improves the understanding of formation mechanisms and potential sources of secondary aerosol. This study was conducted in a rural township in central Taiwan, where the air pollution level was comparable with that in the urban area. Bihourly measurements were applied into an enhanced receptor modeling approach using positive matrix factorization (PMF). Eight potential sources, including oil combustion, coal combustion, secondary aerosol related, nitrate-rich secondary aerosol, biomass burning, industry/vehicle, road dust, and SOM-rich (dominated by secondary organic matter) secondary aerosol, were identified. SOM-rich secondary aerosol (24\%) contributed the most to $\mathrm{PM}_{2.5}$ mass, followed by biomass burning (19\%) and nitrate-rich secondary aerosol $(18 \%)$. Contributions from three factors involving secondary formation features accounted for $55 \%$ of $\mathrm{PM}_{2.5}$ mass. Through the enhanced modeling approach, photo-oxidation formation, condensation and aqueous phase oxidation of volatile organic compounds, and transport of secondary nitrates from upwind urban area could be potential formation process and sources of secondary aerosol.
\end{abstract}

Received: September 6, 2020

Revised: December 7, 2020

Accepted: December 8, 2020

Keywords: Fine particulate matter ( $\mathrm{PM}_{2.5}$ ), Positive matrix factorization (PMF), Multilinear Engine (ME), Source apportionment, Photochemical strength

${ }^{*}$ Corresponding Authors:

Charles C.-K. Chou

ckchou@rcec.sinica.edu.tw

Chang-Fu Wu

changfu@ntu.edu.tw

\section{Publisher:}

Taiwan Association for Aerosol Research

ISSN: $1680-8584$ print

ISSN: 2071-1409 online

(c) Copyright: The Author(s). This is an open access article distributed under the terms of the Creative Commons Attribution License (CC BY 4.0), which permits unrestricted use, distribution, and reproduction in any medium, provided the original author and source are cited.

\section{INTRODUCTION}

Over the past decades, $\mathrm{PM}_{2.5}$ (particulate matter with aerodynamic diameter less than or equal to $2.5 \mu \mathrm{m}$ ) has raised great concern due to its adverse health effects and inevitable exposures (Bell et al., 2013; Kim et al., 2015; Lu et al., 2015). Identifying the $\mathrm{PM}_{2.5}$ sources and quantifying their contributions will be beneficial in improving emission control strategies, therefore reducing $\mathrm{PM}_{2.5}$ exposures. Quantification of source contribution estimates can be achieved through receptor-oriented source apportionment approaches, including effective variance-chemical mass balance (EV-CMB) and positive matrix factorization (PMF) (Hopke, 2016).

The multivariate PMF solution requires less a priori information regarding the emission profiles as compared to EV-CMB. Given a selected number of factors [ $p$ in Eq. (1)], the PMF solution iteratively calculates $g_{i k}$ (factor contribution) and $f_{k j}$ (factor profile) with non-negativity constraint on them to fit $x_{i j}$ (speciated concentration data). The iteration achieves convergence after obtaining small gradient decrease of objective function Q (Paatero and Tapper, 1994; Viana et al., 2008; Belis et al., 2013; Hopke, 2016): 
$Q=\sum_{i=1}^{n} \sum_{j=1}^{m}\left(\frac{e_{i j}}{u_{i j}}\right)^{2}=\sum_{i=1}^{n} \sum_{j=1}^{m}\left(\frac{x_{i j}-\sum_{k=1}^{p} g_{i k} f_{k j}}{u_{i j}}\right)^{2}$

where $i$ denotes index of samples, $n$ is the sample size, $j$ denotes index of species, $m$ represents the number of species, $e_{i j}$ is the residual matrix, and $u_{i j}$ denotes the measurement uncertainty.

Conventional source apportionment approaches using $\mathrm{PM}_{2.5}$ speciation data generally relied on measurements of elements, water-soluble ions and carbonaceous compositions from timeintegrated filter samples (e.g., daily). Modeling results across studies indicated that secondary aerosol keeps being one of the main source types worldwide (Hopke et al., 2006; Viana et al., 2008; Belis et al., 2013; Zhu et al., 2018). In these studies, this source factor was typically identified with high loadings of ammonium, nitrate and/or sulfate ions, which can be generated from secondary formation that involves with complicated gas-to-particle transformation (Watson et al., 1994; Hopke, 2016). Another common feature of these studies is that meteorological data such as wind direction (WD) and wind speed (WS) were applied in the post hoc analysis to identify the possible locations of retrieved sources (Heo et al., 2009; Wimolwattanapun et al., 2011; Hopke, 2016).

Nonetheless, there remained a potential gap between retrieved secondary aerosol factors and actual source origins, which caused a challenge in designing effective control strategies. Additionally, it is important to reveal the rapid atmospheric processes of secondary aerosol formation that is not available from 12-h or 24-h integrated filter samples. Applying high temporal resolution data in receptor modeling could not only enhance the characterization of diurnal patterns of source contributions but also improve the understanding of formation mechanisms and potential sources of secondary aerosol (Lioy et al., 1989; Solomon and Sioutas, 2008; Petit et al., 2014; Tian et al., 2017; Wang et al., 2018; Belis et al., 2019; Srivastava et al., 2019).

An expanded PMF model, first described and detailed by Paatero and Hopke (2002), included parametric variables through an additional equation that can be expressed using the most basic form as (Paatero and Hopke, 2002; Kim et al., 2003b; Begum et al., 2005):

$x_{i j}=\sum_{k=1}^{p} D\left(\delta_{i}, k\right) V\left(v_{i}, k\right) f_{k j}+e_{i j}^{\prime}$

where $D$ represents the WD matrix and $V$ is the WS matrix. $\delta_{i}$ and $v_{i}$ are index parameters obtained from the classification of the wind data. Previous studies demonstrated the benefits of utilizing wind and time variables in the expanded PMF modeling, e.g., a diesel factor can be separated from vehicle exhaust due to reduced rotational ambiguity (Kim et al., 2003b; Begum et al., 2005). Rotational ambiguity, which results from rotation of the factor matrices and could lead to infinite solutions in PMF modeling, can be expressed as (Paatero et al., 2002; Norris et al., 2009; Paatero and Hopke, 2009):

$X=G F+E=G T T^{-1} F+E=\bar{G} \bar{F}+E$

Conceptually, additional environmental characteristics, apart from the wind data, also can be considered in the expanded PMF modeling. For example, photochemical strength and relative humidity $(\mathrm{RH})$ could play important roles in the formation process of secondary aerosol and serve as the parametric variables.

To address above issues and to better understand the sources of secondary aerosol, in this Technical Note we attempted to evaluate the effects of applying an expanded PMF model with bihourly speciation data. Parametric variables, including WS, photochemical strength and RH, were imposed to selected factors involving secondary formation features.

\section{METHODS}

\subsection{Field Data}

An intensive field campaign was conducted in Zhushan $\left(23.76^{\circ} \mathrm{N}, 120.68^{\circ} \mathrm{E}\right)$, a hillside township located in central Taiwan, in late autumn (27 October-6 November) of 2018. Zhushan is in a rural 
area with few industrial sources and low road traffic intensity. Nonetheless, $\mathrm{PM}_{2.5}$ mass concentrations in Zhushan were comparable with those in the urban area (Tsai et al., 2016). This phenomenon is partially explained by the fact that particles can be transported from upwind urban area by sea breezes during daytime (Tsai et al., 2008; Tsai et al., 2016). The sampling site was set up in the downtown area of Zhushan township. The northwest and north-northeast winds were most predominant during the study period. Hourly measurements (mean \pm SD) of wind speed, temperature, and relative humidity were $0.98 \pm 0.59 \mathrm{~m} \mathrm{~s}^{-1}, 23.0 \pm 3.3^{\circ} \mathrm{C}$, and $77.8 \pm 14.0 \%$, respectively.

Bihourly $\mathrm{PM}_{2.5}$ samples were collected on $150 \mathrm{~mm}$ Whatman cellulose filters using high-volume samplers (HVS, DHA-80, DIGITEL) at a flow rate of 500 LPM for the measurement of elements and water-soluble ions. Elemental compositions were analyzed using an inductively coupled plasma mass spectrophotometer (ICP-MS, NexION 300X, Perkin Elmer). Water-soluble ions were quantified by ion chromatography (IC, Dionex ICS 1000, Thermo Scientific). Cellulose and Teflon filters are preferred for analysis of inorganic species, especially trace elements, because of their low backgrounds (Upadhyay et al., 2009). The advantage of using cellulose filters is that they can be completely acid-digested and have high recoveries of trace metals in the ICP-MS analysis (Pekney and Davidson, 2005; Upadhyay et al., 2009).

Additionally, three continuous/semi-continuous instruments were incorporated at the same site. Organic matter (OM) concentrations were obtained from Aerosol Mass Spectrometer (AMS, mini-AMS, Aerodyne) datasets. The AMS datasets were not directly used due to the difficulty of harmonizing mass spectra with inorganic speciation data, but deserve further investigation. Elemental carbon (EC) was monitored using a Multi-Angle Absorption Photometer (MAAP, Model 5012, Thermo-Fisher Scientific). PM2.5 mass concentrations were measured using a Tapered Element Oscillating Microbalance (TEOM, 1405DF, Thermo Electron) monitor. Above measurements were further averaged to bihourly means to match the temporal resolutions of filter samples.

Typically, secondary inorganic aerosol (SIA) can be estimated as the summation of ammonium, nitrate and sulfate ions, which represents the reactions of ammonia $\left(\mathrm{NH}_{3}\right)$ with nitric acid $\left(\mathrm{HNO}_{3}\right.$ from $\left.\mathrm{NO}_{2}\right)$ and sulfuric acid $\left(\mathrm{H}_{2} \mathrm{SO}_{4}\right.$ from $\left.\mathrm{SO}_{2}\right)$ (Behera and Sharma, 2011; Huang et al., 2016). Secondary organic aerosol (SOA) is thought to be formed through photochemical reactions of volatile organic compounds (VOCs), followed by nucleation and/or condensation, and cannot yet be directly measured (Ervens et al., 2011; Al-Naiema et al., 2018; Belis et al., 2019). In order to determine secondary organic contributions to $\mathrm{PM}_{2.5}$, primary and secondary OM (POM and SOM) were calculated using Eq. (6) (Turpin and Huntzicker, 1995; Chou et al., 2010; Wu and Yu, 2016):

$S O M=O M_{\text {total }}-P O M=O M_{\text {total }}-(O M / E C)_{p r i} \times E C$

where $(\mathrm{OM} / \mathrm{EC})_{\text {pri }}$ was determined using the minimum $\mathrm{R}$ squared (MRS) method (Wu and $\mathrm{Yu}$, 2016). In brief, the MRS method approximate (OM/EC) pri that generates the minimum $R^{2}$ between SOM and EC. As shown in Fig. S1, the (OM/EC) pri was estimated to be 3.20 during the study period.

In addition to the particulate data, hourly measurements of gaseous pollutants (i.e., $\mathrm{SO}_{2}, \mathrm{NO}$, $\mathrm{NO}_{2}, \mathrm{O}_{3}$ and $\mathrm{CO}$ ) and meteorological parameters, including WD, WS, temperature and $\mathrm{RH}$, were acquired from the Zhushan Air Quality Monitoring Station (Zhushan AQMS) of the Taiwan Environmental Protection Administration (TEPA). Odd oxygen (Ox), calculated as $\left[\mathrm{O}_{3}\right]+\left[\mathrm{NO}_{2}\right]$, was utilized to represent the photochemical strength (Wood et al., 2010; Li et al., 2018).

\subsection{Receptor Modeling}

The script-based Multilinear Engine (ME-2) program that allowed modifying and implementing additional equations was used to execute the expanded PMF modeling. In this study, Eq. (4) is modified to incorporate hourly parametric variables, including WS, $\mathrm{RH}$ and $\mathrm{Ox}$, as follows:

$x_{i j}=\sum_{k=1}^{p}\left[\sum_{h=1}^{2} V\left(v_{i h}, k\right) R\left(\rho_{i h}, k\right) O\left(o_{i h}, k\right)\right] f_{k j}+e_{i j}^{\prime}$

where $V, R$ and $O$ represent the WS, $\mathrm{RH}$ and $O x$ matrices. The classifications of the parametric data were defined to give approximately equivalent sample sizes across the intervals of each 
index parameter $(v, \rho$ and $o)$. During the study period, more than half of the WS measurements were smaller than $1 \mathrm{~m} \mathrm{~s}^{-1}$, which could result in unreliable WD data (Kim et al., 2003b; Buset et al., 2006). Therefore, WD was not incorporated in this study. The expanded PMF modeling was conducted through a 2-step run. The base run retrieved source contribution estimates $\left(g_{i k}\right)$ and source factors $\left(f_{k j}\right)$ using the ordinary bilinear equations as Eq. (2). The expanded run applied additional equations as Eq. (7) to selected factors involving secondary formation features. The objective function $Q$ was re-defined accordingly through adding an expanded term:

$$
Q=\sum_{i=1}^{n} \sum_{j=1}^{m}\left(\frac{e_{i j}}{u_{i j}}\right)^{2}+\sum_{i=1}^{n} \sum_{j=1}^{m}\left(\frac{e_{i j}^{\prime}}{u_{i j}^{\prime}}\right)^{2}
$$

In addition to the observed data, measurement uncertainties were required as the model input. The uncertainty for each observation was calculated as (Liao et al., 2017b):

$$
u_{i j}=\sqrt{\left(0.5 \times M D L_{j}\right)^{2}+\left(0.1 \times x_{i j}\right)^{2}}
$$

where $M D L_{j}$ denotes the method detection limit (MDL) of species $\mathrm{j}$. Each concentration value below the MDL was replaced by MDL/2 with its uncertainty set to $(5 / 6) \times M D L$. Additionally, only species having more than $30 \%$ of detectable values were included in the PMF modeling. Although the matrices, V, R and O, in Eq. (7) contained factor elements to be estimated, the chemical mass balance equation [Eq. (2)] should be more dominant in the fitting process. Therefore, the expanded equations were assigned greater uncertainties [ $u_{i j}^{\prime}$ in Eq. (8)] than the corresponding measurement uncertainties (Paatero and Hopke, 2002).

The maximum individual column mean (IM) and the maximum individual column standard deviation (IS) were calculated from the residual matrix to approximate the optimal number of factors in the base model run (Lee et al., 1999):

$$
\begin{aligned}
& I M=\max _{j=1 \ldots m}\left(\frac{1}{n} \sum_{i=1}^{n} \frac{e_{i j}}{u_{i j}}\right) \\
& I S=\max _{j=1 \ldots m}\left(\sqrt{\frac{1}{n-1} \sum_{i=1}^{n}\left(\frac{e_{i j}}{u_{i j}}-\frac{1}{n} \sum_{i=1}^{n} \frac{e_{i j}}{u_{i j}}\right)^{2}}\right)
\end{aligned}
$$

An obvious decrease in IM and IS was expected around the optimal number of factors (Lee et al., 1999; Liao et al., 2020). The retrieved profiles were interpreted by examining the mass fractions and explained variations (EVs) of specific species (Lee et al., 1999; Liao et al., 2017b):

$$
E V_{k j}=\left[1-\left(\sum_{i=1}^{n} e_{i j}^{2} / u_{i j}^{2}\right) /\left(\sum_{i=1}^{n} x_{i j}^{2} / u_{i j}^{2}\right)\right] \times f_{k j} / \sum_{k=1}^{p} f_{k j}
$$

\section{RESULTS AND DISCUSSION}

The final model input is a matrix with 116 rows (bihourly concentration data) and 28 columns ( $P M_{2.5}$ and its species) after screening invalid data. Table 1 shows the distribution of concentrations of each species included in the PMF modeling. Ammonium ion, nitrate ion, sulfate ion, POM and SOM were the major constituents ( $>12 \%$ for each) of $\mathrm{PM}_{2.5}$. These components, except for POM, are regarded as secondary aerosol and accounted for over $60 \%$ of $\mathrm{PM}_{2.5}$ mass. After a sequence of model runs with different number of factors, an 8-factor solution (Fig. 1) seemed most reasonable, having a high correlation (0.87) between observed/predicted $\mathrm{PM}_{2.5}$ mass and well model fitting (>0.68) for all species (Kuo et al., 2014; Liao et al., 2017a).

Factor01, enriched in SOM, sulfate ion, ammonium ion and POM, is characterized by high EV 
Table 1. Summary statistics of speciated data used in PMF modeling $(n=116)$.

\begin{tabular}{|c|c|c|c|c|c|}
\hline Species & Abbreviation & Average & Median & $\mathrm{P} 25^{a}$ & $\mathrm{P} 75^{b}$ \\
\hline $\mathrm{PM}_{2.5}$ Mass $\left(\mu \mathrm{g} \mathrm{m}^{-3}\right)$ & fPM & 29.00 & 28.91 & 22.20 & 35.89 \\
\hline \multicolumn{6}{|l|}{ Element $\left(\mathrm{ng} \mathrm{m}^{-3}\right)$} \\
\hline Aluminium & Al & 206.83 & 173.49 & 77.96 & 281.77 \\
\hline Titanium & $\mathrm{Ti}$ & 15.90 & 14.30 & 9.14 & 18.24 \\
\hline Vanadium & V & 1.83 & 1.83 & 1.24 & 2.27 \\
\hline Manganese & $\mathrm{Mn}$ & 13.72 & 12.77 & 8.64 & 17.30 \\
\hline Iron & $\mathrm{Fe}$ & 431.94 & 470.24 & 410.69 & 512.00 \\
\hline Copper & $\mathrm{Cu}$ & 11.65 & 11.46 & 10.39 & 12.68 \\
\hline Zinc & $\mathrm{Zn}$ & 62.87 & 56.92 & 43.99 & 69.02 \\
\hline Arsenic & As & 1.10 & 1.08 & 0.77 & 1.24 \\
\hline Selenium & $\mathrm{Se}$ & 0.93 & 0.84 & 0.57 & 1.19 \\
\hline Rubidium & $\mathrm{Rb}$ & 0.84 & 0.66 & 0.48 & 1.14 \\
\hline Strontium & $\mathrm{Sr}$ & 2.04 & 1.62 & 1.30 & 2.84 \\
\hline Yttrium & Y & 0.07 & 0.05 & 0.03 & 0.09 \\
\hline Molybdenum & Mo & 0.78 & 0.76 & 0.63 & 0.89 \\
\hline Caesium & Cs & 0.05 & 0.03 & 0.02 & 0.07 \\
\hline Lanthanum & La & 0.14 & 0.12 & 0.07 & 0.18 \\
\hline Cerium & $\mathrm{Ce}$ & 0.23 & 0.20 & 0.12 & 0.30 \\
\hline Thallium & $\mathrm{Tl}$ & 0.08 & 0.05 & 0.03 & 0.13 \\
\hline Lead & $\mathrm{Pb}$ & 13.11 & 11.55 & 7.61 & 17.28 \\
\hline \multicolumn{6}{|l|}{ Water-soluble ion $\left(\mu \mathrm{g} \mathrm{m}^{-3}\right)$} \\
\hline Sodium ion & Na_ion & 0.40 & 0.37 & 0.31 & 0.47 \\
\hline Potassium ion & K_ion & 0.26 & 0.25 & 0.14 & 0.36 \\
\hline Ammonium ion & NH4_ion & 3.71 & 3.52 & 3.11 & 4.25 \\
\hline Chloride ion & Cl_ion & 0.63 & 0.63 & 0.41 & 0.77 \\
\hline Nitrate ion & NO3_ion & 4.70 & 4.15 & 3.14 & 5.56 \\
\hline Sulfate ion & SO4_ion & 3.62 & 3.69 & 2.40 & 4.49 \\
\hline \multicolumn{6}{|c|}{ Carbonaceous composition ( $\mu \mathrm{g} \mathrm{m}^{-3}$ ) } \\
\hline Primary organic matter & POM & 5.40 & 5.16 & 3.74 & 6.58 \\
\hline Secondary organic matter & SOM & 7.43 & 6.81 & 5.33 & 8.97 \\
\hline Elemental carbon & EC & 1.69 & 1.61 & 1.17 & 2.06 \\
\hline
\end{tabular}

${ }^{a}$ P25: $25^{\text {th }}$ percentile.

${ }^{b}$ P75: $75^{\text {th }}$ percentile.

of $\mathrm{V}$ that is associated with residual oil combustion (Swietlicki and Krejci, 1996; Lee et al., 1999; Pakkanen et al., 2003; Sun et al., 2004; Pandolfi et al., 2011). In Taiwan, oil-fired boilers, ship emissions and port activities are considered main sources of oil combustion (Hsu et al., 2005; Hsu et al., 2017). Factor02, characterized by high EV of As, Se and TI along with high loadings of sulfate ion and ammonium ion, is associated with coal combustion (Han et al., 2006; Antonia López Antón et al., 2013). Factor03 is associated with a secondary aerosol related source by high loadings of sulfate ion, nitrate ion, ammonium ion and SOM without specific markers. Factor04, characterized by both high loading and high EV of nitrate ion, is interpreted as nitrate-rich secondary aerosol. Factor05 is associated with biomass burning, characterized by potassium ion, POM and EC (Streets et al., 2001; Cheng et al., 2009; Gugamsetty et al., 2012). Factor06, loaded on nitrate ion, ammonium ion, POM, SOM and EC along with high EVs of $\mathrm{Mn}, \mathrm{Fe}, \mathrm{Cu}, \mathrm{Zn}, \mathrm{Mo}$ and chloride ion, is interpreted as a mixed source of traffic and industrial emissions (Larsen and Baker, 2003; Han et al., 2006; Gugamsetty et al., 2012; Jain et al., 2017). Factor07 has high EVs of crustal (Al and Ti) and rare earth ( $\mathrm{Y}$, La and $\mathrm{Ce}$ ) elements, and is thus associated with road dust (Kim et al., 2003a; Wimolwattanapun et al., 2011; Gugamsetty et al., 2012; Kara et al., 2015). Factor08 is interpreted as SOM-rich secondary aerosol, characterized by both high loading and high EV of SOM.

The constituents of secondary aerosol (i.e., sulfate ion, nitrate ion, ammonium ion and SOM) were partially attributed to primary sources, e.g., the profile of biomass burning contained a small fraction of these components. Nevertheless, a large proportion of them was differentiated into 


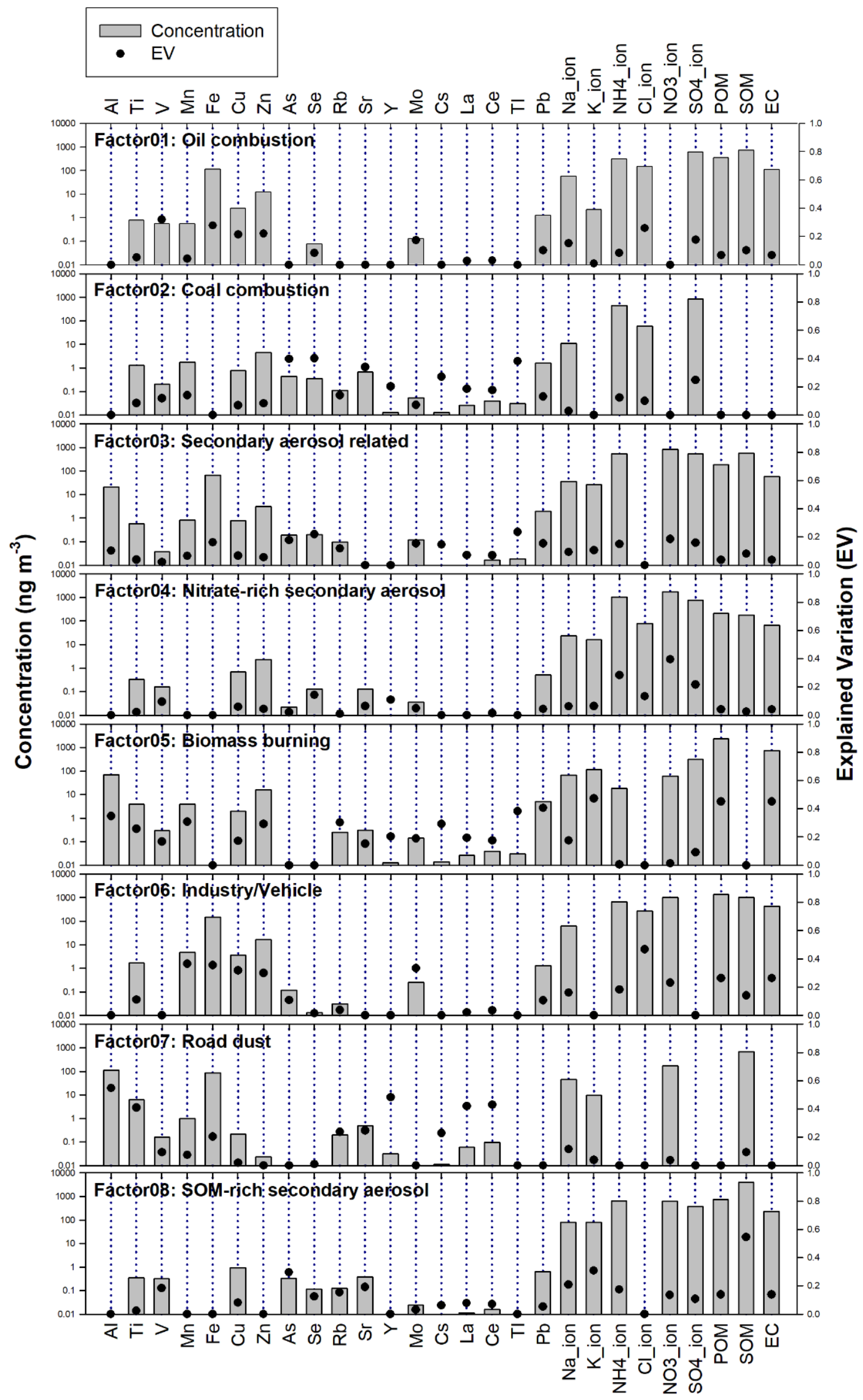

Fig. 1. Factor profiles of base model run plotted as mass concentration (concentration unit, gray bar) and explained variation (0 to 1 , black circle) of each chemical species. 
three factors (Factor03, Factor04 and Factor08) that showed non-specific source characteristics. To better understand the sources of secondary aerosol, the above-mentioned three factors were chosen as the target factors in expanded PMF modeling.

As shown in Fig. 2, both FactorO3 and Factor04 showed higher contribution estimates during daytime but with different diurnal patterns. Factor03 exhibited a peak maximum in the early afternoon (12-14 local time), whereas Factor04 had highest contribution in the late morning (1012 local time). On the other hand, Factor08 showed higher contribution estimates during nighttime. Difference in diurnal patterns indicated different formation mechanisms or source origins among these three factors. Expanded model results for these secondary factors are shown in Fig. 3. Factor03 was not correlated with wind speed but showed obvious trends with increasing photochemical strength and reducing humidity. It might indicate that Factor03 was involved with locally accumulated secondary aerosol formation from photochemical reaction. In contrast, Factor08 was not well correlated with $\mathrm{Ox}$ or $\mathrm{RH}$ but demonstrated an apparent drop as WS increased, indicating that Factor08 could be associated with condensation of VOCs under low wind speed conditions during nighttime. Saffari et al. (2016) revealed that the nighttime SOC/OC ratio was increased at $\mathrm{RH}$ above $70 \%$, indicating enhanced aqueous phase formation of SOC. It may partially explain the decrease of contribution of Factor08 at $\mathrm{RH}<69 \%$. Factor04 exhibited slightly increasing trends with increasing WS, escalating Ox and reducing $\mathrm{RH}$, suggesting that Factor04 might involve with photochemical reaction and transportation of secondary aerosol originated from more distant areas.

To examine the transport of air pollutants from upwind source regions, back trajectory analyses were applied to the top ten contribution periods of FactorO4 using the HYbrid Single-Particle Lagrangian Integrated Trajectory (HYSPLIT-4) model (Draxler and Rolph, 2015; Rolph, 2015; Stein et al., 2015). Twenty-four-hour back trajectories were computed using meteorological data from the Weather Research and Forecasting (WRF) model simulation with a 1-km grid spacing (Skamarock and Klemp, 2008; Lin et al., 2017). The initial meteorological condition was from ds083.3 NCEP GDAS/FNL 0.25 Degree Global Tropospheric Analyses and Forecast Grids (DOI: 10.5065/D65Q4T4Z, https://rda.ucar.edu/datasets/ds083.3/). In order to get a better meteorological field, the WRF modeling applied four-dimensional data assimilation with observation nudging. The back trajectory analyses results were demonstrated on a map created using the free and open source QGIS (Fig. S2). $\mathrm{NO}_{\mathrm{x}}$ emission inventory data obtained from Taiwan Emission Data System version 10.0

$02246 \quad 8 \quad 10121416182022$

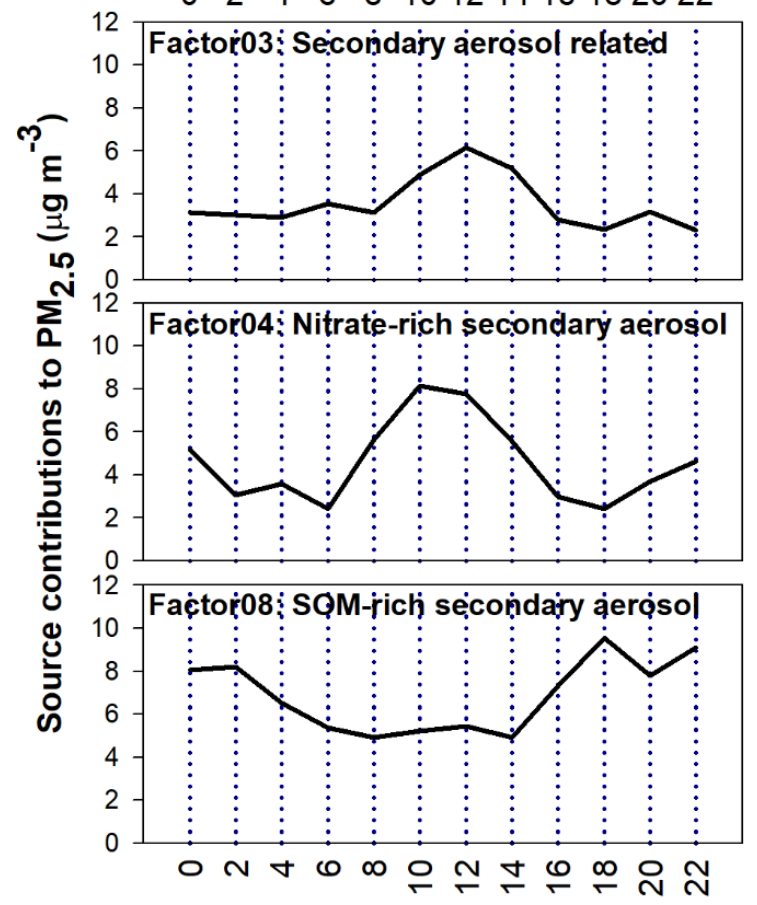

Fig. 2. Diurnal patterns of source contributions for the secondary sources. 
Factor03
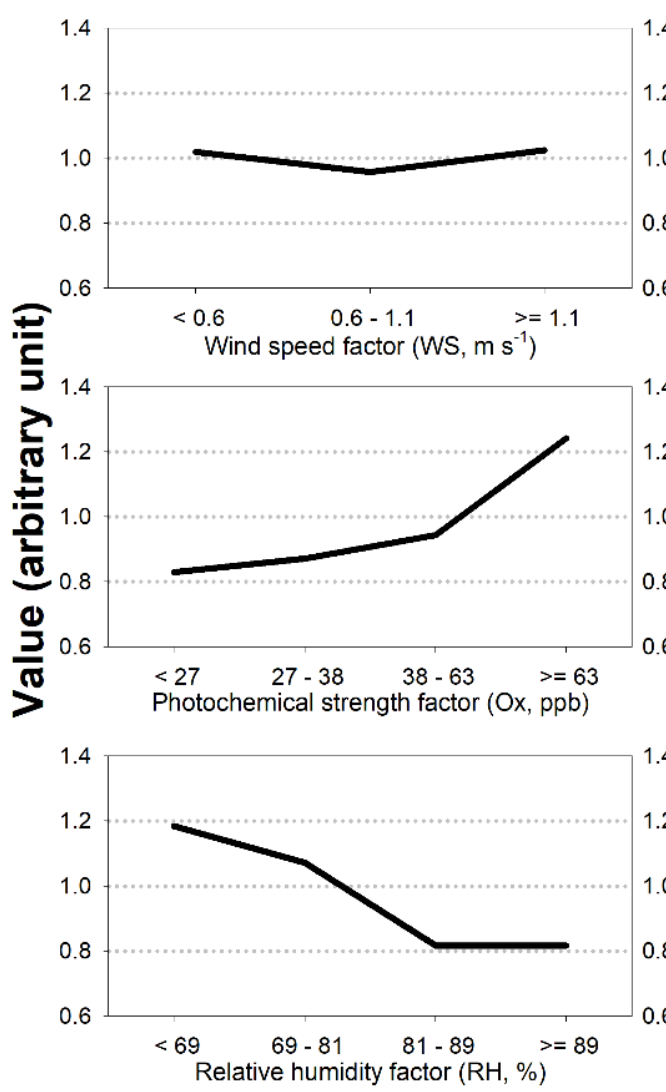

Factor04

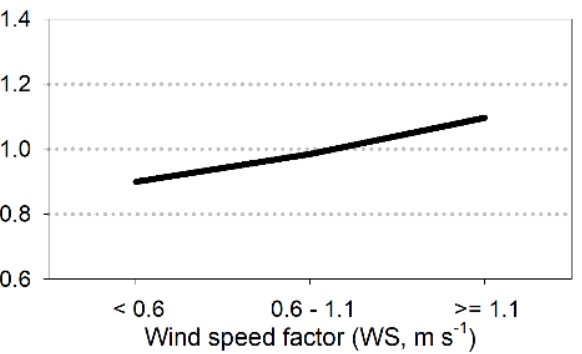

Wind speed factor (WS, $\mathrm{m} \mathrm{s}^{-1}$ )
Factor08

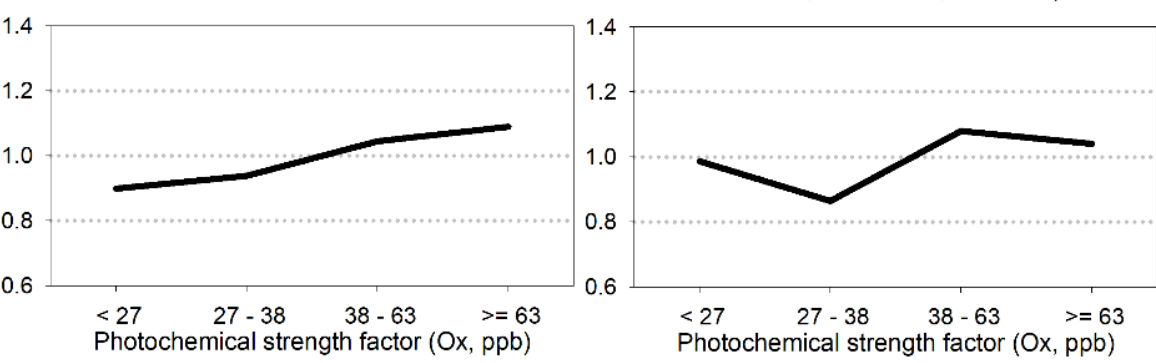

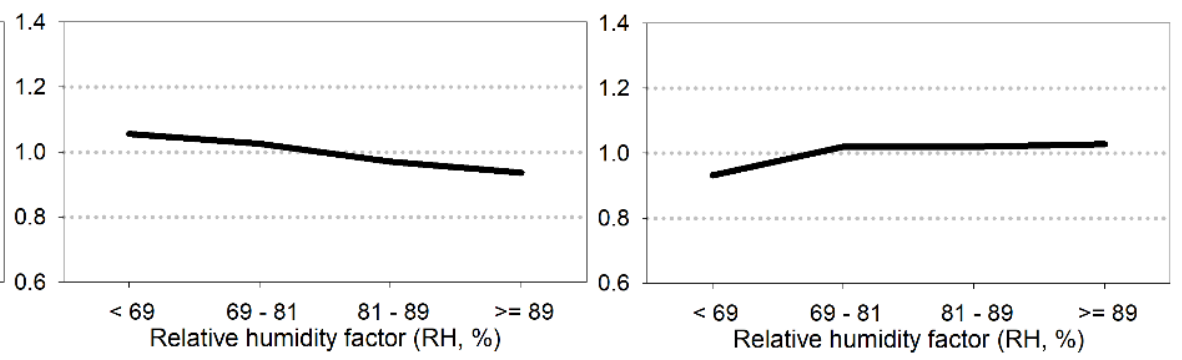

Fig. 3. Expanded model results showing the relationships of source contributions with wind speed (WS), photochemical strength $(\mathrm{Ox})$ and relative humidity $(\mathrm{RH})$ for the secondary sources.

(TEDS 10.0) was also illustrated on the map. Results indicated that high contribution periods of Factor04 had the pathway passing through urban areas with high $\mathrm{NO}_{\mathrm{x}}$ emissions, specifically the Taichung metropolis. Since low $\mathrm{NO}_{x}$ emissions were reported at the sampling site, upwind urban area was likely the origin of high contributions of secondary nitrates.

Average source contribution estimates to $\mathrm{PM}_{2.5}$ mass during the campaign period are shown in Fig. 4. The greatest contributor was SOM-rich secondary aerosol (Factor08, 24\%), followed by biomass burning (Factor05, 19\%) and nitrate-rich secondary aerosol (Factor04, 18\%). Contributions from three factors involving secondary formation features (Factor03, Factor04 and Factor08) accounted for $55 \%$ of $\mathrm{PM}_{2.5}$ mass, which could have a considerable impact on air quality at the Zhushan area. In addition to photo-oxidation formation, condensation and aqueous phase oxidation of VOCs and transport of secondary nitrates could be important PM $_{2.5}$ sources during the campaign period. On the other hand, previous studies also indicated biomass burning as an important source in central Taiwan partially due to the intense burning activities in the harvest season (Yang et al., 2006; Cheng et al., 2009; Liao et al., 2015; Tsai et al., 2016; Lee et al., 2019).

It should be noted that although several previous studies have revealed better results in the expanded PMF modeling (Kim et al., 2003b; Begum et al., 2005; Buset et al., 2006), no improvement was found than the normal PMF analysis in other researches, e.g., Zhou et al. (2009). Thus, multiple models should be explored to ensure that the most reliable solution has been obtained. Another limitation of this study is that the intensive 10-day field campaign was unable to assess long-term exposure to $\mathrm{PM}_{2.5}$ in the study area. In addition, time variables such as season and weekend effects were not considered in this study due to the same issue. Nonetheless, this study exhibited the benefits of application of expanded PMF modeling with parametric variables in improving characterization of the formation mechanisms and potential sources of secondary aerosol. Further investigation of SOA tracers would be beneficial in identifying the source origins of VOCs that are associated with SOA formation. 


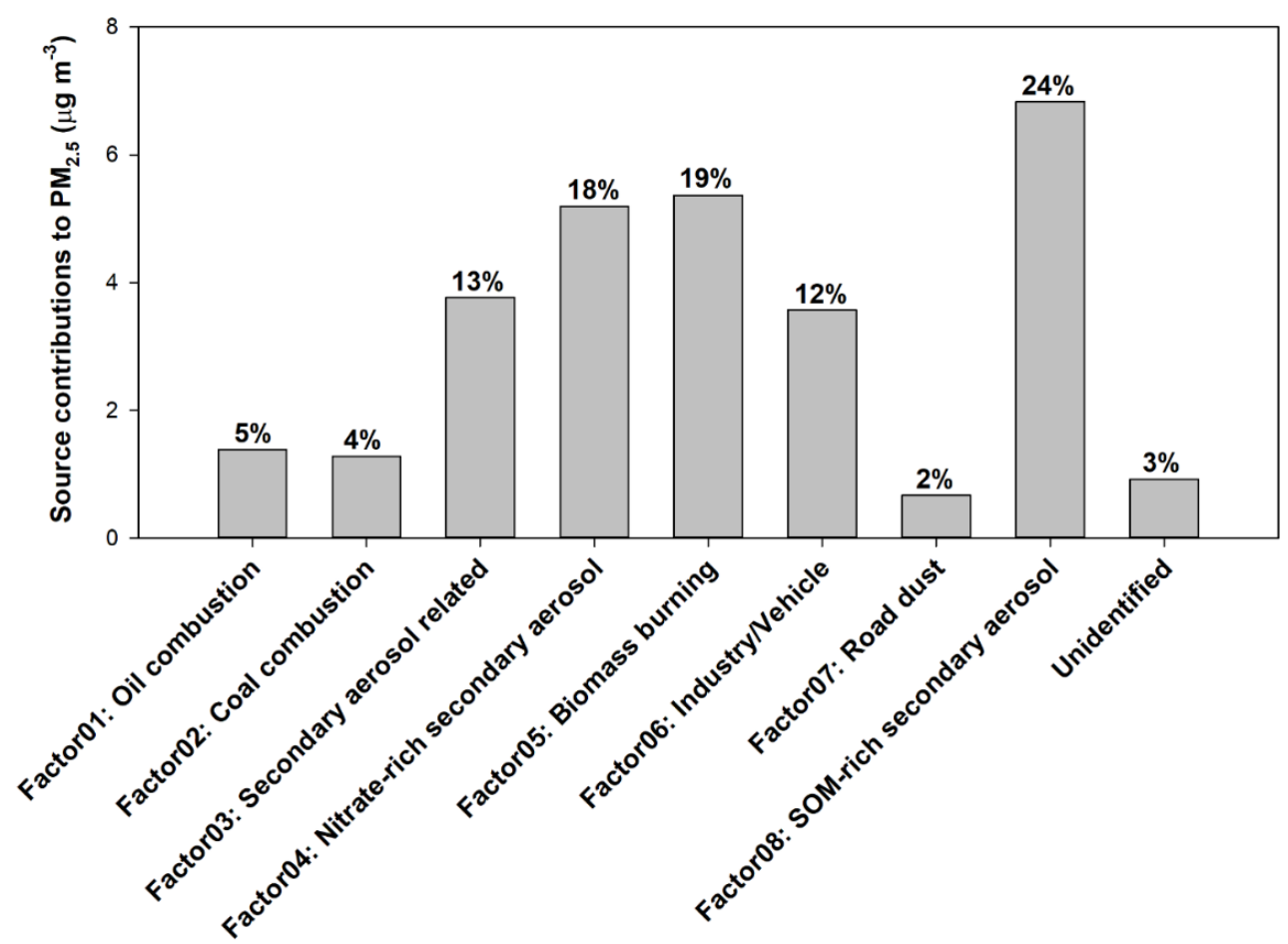

Fig. 4. Source contribution estimates to $P M_{2.5}$ mass at the Zhushan sampling site during the study period (27 October-6 November, 2018).

\section{CONCLUSIONS}

In this study an expanded PMF modeling approach was applied to bihourly $\mathrm{PM}_{2.5}$ speciation data. Results indicated that SOM-rich secondary aerosol contributed the most (24\%) among the eight apportioned factors. Through the enhanced modeling approach, this factor could be associated with condensation and aqueous phase oxidation of VOCs, suggesting the need for further investigation of SOA tracers. The second largest contributor (biomass burning, 19\%) might be abated through regulating open field burning activities. The third largest factor (nitrate-rich secondary aerosol, 18\%) was characterized to be more likely the transport of secondary nitrates from upwind metropolitan area during the campaign period. Cooperation between neighboring cities would be more cost-effective in reducing its contribution to PM air pollution.

\section{ACKNOWLEDGMENTS}

This study was supported in part by the Ministry of Science and Technology of Taiwan (MOST 106-2221-E-002-021-MY3, 109-2221-E-002-057-MY3, 106-3114-M-001-001-A, 108-2119-M-001008-A, and 109-2119-M-001-009-A) and the Featured Areas Research Center Program within the framework of the Higher Education Sprout Project by the Ministry of Education of Taiwan (NTU107L9003, NTU-108L9003, and NTU-109L9003).

\section{DISCLAIMER}

The authors declare that there are no conflicts of interest.

\section{SUPPLEMENTARY MATERIAL}

Supplementary data associated with this article can be found in the online version at https://doi.org/10.4209/aaqr.200549 


\section{REFERENCES}

Al-Naiema, I.M., Hettiyadura, A.P.S., Wallace, H.W., Sanchez, N.P., Madler, C.J., Cevik, B.K., Bui, A.A.T., Kettler, J., Griffin, R.J., Stone, E.A. (2018). Source apportionment of fine particulate matter in Houston, Texas: Insights to secondary organic aerosols. Atmos. Chem. Phys. 18 15601-15622. https://doi.org/10.5194/acp-18-15601-2018

Antonia López Antón, M., Alan Spears, D., Somoano, M.D., Rosa Martínez Tarazona, M. (2013). Thallium in coal: Analysis and environmental implications. Fuel 105, 13-18. https://doi.org/10. 1016/j.fuel.2012.08.004

Begum, B.A., Hopke, P.K., Zhao, W. (2005). Source identification of fine particles in Washington, DC, by expanded factor analysis modeling. Environ. Sci. Technol. 39, 1129-1137. https://doi.org/10.1021/es049804v

Behera, S.N., Sharma, M. (2011). Degradation of $\mathrm{SO}_{2}, \mathrm{NO}_{2}$ and $\mathrm{NH}_{3}$ leading to formation of secondary inorganic aerosols: An environmental chamber study. Atmos. Environ. 45, 40154024. https://doi.org/10.1016/j.atmosenv.2011.04.056

Belis, C.A., Karagulian, F., Larsen, B.R., Hopke, P.K. (2013). Critical review and meta-analysis of ambient particulate matter source apportionment using receptor models in Europe. Atmos. Environ. 69, 94-108. https://doi.org/10.1016/j.atmosenv.2012.11.009

Belis, C.A., Pikridas, M., Lucarelli, F., Petralia, E., Cavalli, F., Calzolai, G., Berico, M., Sciare, J. (2019). Source apportionment of fine PM by combining high time resolution organic and inorganic chemical composition datasets. Atmos. Environ. 3, 100046. https://doi.org/10.1016/j.aeaoa.2 019.100046

Bell, M.L., Zanobetti, A., Dominici, F. (2013). Evidence on vulnerability and susceptibility to health risks associated with short-term exposure to particulate matter: A systematic review and metaanalysis. Am. J. Epidemiol. 178, 865-876. https://doi.org/10.1093/aje/kwt090

Buset, K.C., Evans, G.J., Richard Leaitch, W., Brook, J.R., Toom-Sauntry, D. (2006). Use of advanced receptor modelling for analysis of an intensive 5-week aerosol sampling campaign. Atmos. Environ. 40, 482-499. https://doi.org/10.1016/j.atmosenv.2005.12.074

Cheng, M.T., Horng, C.L., Su, Y.R., Lin, L.K., Lin, Y.C., Chou, C.C.K. (2009). Particulate matter characteristics during agricultural waste burning in Taichung City, Taiwan. J. Hazard. Mater. 165, 187-192. https://doi.org/10.1016/j.jhazmat.2008.09.101

Chou, C.C.K., Lee, C.T., Cheng, M.T., Yuan, C.S., Chen, S.J., Wu, Y.L., Hsu, W.C., Lung, S.C., Hsu, S.C., Lin, C.Y., Liu, S.C. (2010). Seasonal variation and spatial distribution of carbonaceous aerosols in Taiwan. Atmos. Chem. Phys. 10, 9563-9578. https://doi.org/10.5194/acp-10-9563-2010

Draxler, R.R., Rolph, G.D. HYSPLIT (HYbrid Single-Particle Lagrangian Integrated Trajectory) Model access via NOAA ARL READY Website, http://ready.noaa.gov/HYSPLIT.php (accessed 17 February, 2021).

Ervens, B., Turpin, B., Weber, R. (2011). Secondary organic aerosol formation in cloud droplets and aqueous particles (aqSOA): A review of laboratory, field and model studies. Atmos. Chem. Phys. 11, 11069-11102. https://doi.org/10.5194/acp-11-11069-2011

Gugamsetty, B., Wei, H., Liu, C.N., Awasthi, A., Hsu, S.C., Tsai, C.J., Roam, G.D., Wu, Y.C., Chen, C.F. (2012). Source characterization and apportionment of $\mathrm{PM}_{10}, \mathrm{PM}_{2.5}$ and $\mathrm{PM}_{0.1}$ by using positive matrix factorization. Aerosol Air Qual. Res. 12, 476-491. https://doi.org/10.4209/aaqr.2012.04. 0084

Han, J.S., Moon, K.J., Lee, S.J., Kim, Y.J., Ryu, S.Y., Cliff, S.S., Yi, S.M. (2006). Size-resolved source apportionment of ambient particles by positive matrix factorization at Gosan background site in East Asia. Atmos. Chem. Phys. 6, 211-223. https://doi.org/10.5194/acp-6-211-2006

Heo, J.B., Hopke, P.K., Yi, S.M. (2009). Source apportionment of PM2.5 in Seoul, Korea. Atmos. Chem. Phys. 9, 4957-4971. https://doi.org/10.5194/acp-9-4957-2009

Hopke, P.K. (2016). Review of receptor modeling methods for source apportionment. J. Air Waste Manag. Assoc. 66, 237-259. https://doi.org/10.1080/10962247.2016.1140693

Hopke, P.K., Ito, K., Mar, T., Christensen, W.F., Eatough, D.J., Henry, R.C., Kim, E., Laden, F., Lall, R., Larson, T.V., Liu, H., Neas, L., Pinto, J., Stolzel, M., Suh, H., Paatero, P., Thurston, G.D. (2006). PM source apportionment and health effects: 1 . Intercomparison of source apportionment results. J. Expo. Sci. Environ. Epidemiol. 16, 275-286. https://doi.org/10.1038/sj.jea.7500458 
Hsu, C.Y., Chiang, H.C., Chen, M.J., Chuang, C.Y., Tsen, C.M., Fang, G.C., Tsai, Y.I., Chen, N.T., Lin, T.Y., Lin, S.L., Chen, Y.C. (2017). Ambient PM2.5 in the residential area near industrial complexes: Spatiotemporal variation, source apportionment, and health impact. Sci. Total Environ. 590, 204-214. https://doi.org/10.1016/j.scitotenv.2017.02.212

Hsu, S.C., Liu, S.C., Jeng, W.L., Lin, F.J., Huang, Y.T., Lung, S.C.C., Liu, T.H., Tu, J.Y. (2005). Variations of $\mathrm{Cd} / \mathrm{Pb}$ and $\mathrm{Zn} / \mathrm{Pb}$ ratios in Taipei aerosols reflecting long-range transport or local pollution emissions. Sci. Total Environ. 347, 111-121. https://doi.org/10.1016/j.1016/j.scitotenv.2004.1 2.021

Huang, X., Liu, Z., Zhang, J., Wen, T., Ji, D., Wang, Y. (2016). Seasonal variation and secondary formation of size-segregated aerosol water-soluble inorganic ions during pollution episodes in Beijing. Atmos. Res. 168, 70-79. http://doi.org/10.1016/j.atmosres.2015.08.021

Jain, S., Sharma, S.K., Choudhary, N., Masiwal, R., Saxena, M., Sharma, A., Mandal, T.K., Gupta, A., Gupta, N.C., Sharma, C. (2017). Chemical characteristics and source apportionment of PM $_{2.5}$ using PCA/APCS, UNMIX, and PMF at an urban site of Delhi, India. Environ. Sci. Pollut. Res. 24, 14637-14656. https://doi.org/10.1007/s11356-017-8925-5

Kara, M., Hopke, P.K., Dumanoglu, Y., Altiok, H., Elbir, T., Odabasi, M., Bayram, A. (2015). Characterization of PM Using multiple site data in a heavily industrialized region of Turkey. Aerosol Air Qual. Res. 15, 11-27. https://doi.org/10.4209/aaqr.2014.02.0039

Kim, E., Hopke, P.K., Edgerton, E.S. (2003a). Source identification of Atlanta aerosol by positive matrix factorization. J. Air Waste Manag. Assoc. 53, 731-739. https://doi.org/10.1080/104732 89.2003.10466209

Kim, E., Hopke, P.K., Paatero, P., Edgerton, E.S. (2003b). Incorporation of parametric factors into multilinear receptor model studies of Atlanta aerosol. Atmos. Environ. 37, 5009-5021. https://doi.org/10.1016/j.atmosenv.2003.08.035

Kim, K.H., Kabir, E., Kabir, S. (2015). A review on the human health impact of airborne particulate matter. Environ. Int. 74, 136-143. https://doi.org/10.1016/j.envint.2014.10.005

Kuo, C.P., Liao, H.T., Chou, C.C., Wu, C.F. (2014). Source apportionment of particulate matter and selected volatile organic compounds with multiple time resolution data. Sci. Total Environ. 472, 880-887. https://doi.org/10.1016/j.scitotenv.2013.11.114

Larsen, R.K., Baker, J.E. (2003). Source apportionment of polycyclic aromatic hydrocarbons in the urban atmosphere: A comparison of three methods. Environ. Sci. Technol. 37, 1873-1881. https://doi.org/10.1021/es0206184

Lee, C.S.L., Chou, C.C.K., Cheung, H.C., Tsai, C.Y., Huang, W.R., Huang, S.H., Chen, M.J., Liao, H.T., Wu, C.F., Tsao, T.M., Tsai, M.J., Su, T.C. (2019). Seasonal variation of chemical characteristics of fine particulate matter at a high-elevation subtropical forest in East Asia. Environ. Pollut. 246, 668-677. https://doi.org/10.1016/j.envpol.2018.11.033

Lee, E., Chan, C.K., Paatero, P. (1999). Application of positive matrix factorization in source apportionment of particulate pollutants in Hong Kong. Atmos. Environ. 33, 3201-3212. https://doi.org/10.1016/S1352-2310(99)00113-2

Li, H., Duan, F., Ma, Y., He, K., Zhu, L., Ma, T., Ye, S., Yang, S., Huang, T., Kimoto, T. (2018). Case study of spring haze in Beijing: Characteristics, formation processes, secondary transition, and regional transportation. Environ. Pollut. 242, 544-554. https://doi.org/10.1016/j.envpol.2018. 07.001

Liao, H.T., Chang, J.C., Tsai, T.T., Tsai, S.W., Chou, C.C.K., Wu, C.F. (2020). Vertical distribution of source apportioned $\mathrm{PM}_{2.5}$ using particulate-bound elements and polycyclic aromatic hydrocarbons in an urban area. J. Exposure Sci. Environ. Epidemiol. 30, 659-669. https://doi.org/10.1038/s41370-019-0153-2

Liao, H.T., Chou, C.C.K., Chow, J.C., Watson, J.G., Hopke, P.K., Wu, C.F. (2015). Source and risk apportionment of selected VOCs and $\mathrm{PM}_{2.5}$ species using partially constrained receptor models with multiple time resolution data. Environ. Pollut. 205, 121-130. http://doi.org/10.1016/j.env pol.2015.05.035

Liao, H.T., Chou, C.C.K., Huang, S.H., Lu, C.J., Chen, C.C., Hopke, P.K., Wu, C.F. (2017a). Source apportionment of $\mathrm{PM}_{2.5}$ size distribution and composition data from multiple stationary sites using a mobile platform. Atmos Res 190, 21-28. http://doi.org/10.1016/j.atmosres.2017.02.008

Liao, H.T., Yau, Y.C., Huang, C.S., Chen, N., Chow, J.C., Watson, J.G., Tsai, S.W., Chou, C.C.K., Wu, C.F. (2017b). Source apportionment of urban air pollutants using constrained receptor models 
with a priori profile information. Environ. Pollut. 227, 323-333. https://doi.org/10.1016/j.envp ol.2017.04.071

Lin, C.C., Chen, W.N., Loftus, A.M., Lin, C.Y., Fu, Y.T., Peng, C.M., Yen, M.C. (2017). Influences of the long-range transport of biomass-burning pollutants on surface air quality during 7-SEAS field campaigns. Aerosol Air Qual. Res. 17, 2595-2607. https://doi.org/10.4209/aaqr.2017.08.0273

Lioy, P.J., Zelenka, M.P., Cheng, M.D., Reiss, N.M., Wilson, W.E. (1989). The effect of sampling duration on the ability to resolve source types using factor-analysis. Atmos. Environ. 23, 239254. https://doi.org/10.1016/0004-6981(89)90116-9

Lu, F., Xu, D.Q., Cheng, Y.B., Dong, S.X., Guo, C., Jiang, X., Zheng, X.Y. (2015). Systematic review and meta-analysis of the adverse health effects of ambient $\mathrm{PM}_{2.5}$ and $\mathrm{PM}_{10}$ pollution in the Chinese population. Environ. Res. 136, 196-204. https://doi.org/10.1016/j.envres.2014.06.029

Norris, G., Vedantham, R., Wade, K., Zahn, P., Brown, S., Paatero, P., Eberly, S., Foley, C. (2009). Guidance document for PMF applications with the Multilinear Engine. U.S. Environmental Protection Agency, Washington, DC. https://cfpub.epa.gov/si/si_public_file_download.cfm?p_ download_id=488084\&Lab=NERL

Paatero, P., Hopke, P.K. (2002). Utilizing wind direction and wind speed as independent variables in multilinear receptor modeling studies. Chemom. Intell. Lab. Syst. 60, 25-41. https://doi.org/ 10.1016/S0169-7439(01)00183-6

Paatero, P., Hopke, P.K. (2009). Rotational tools for factor analytic models. J. Chemometr. 23, 91100. https://doi.org/10.1002/cem.1197

Paatero, P., Tapper, U. (1994). Positive matrix factorization: A non-negative factor model with optimal utilization of error estimates of data values. Environmetrics 5, 111-126. https://doi.org/10.1002/env.3170050203

Paatero, P., Hopke, P.K., Song, X.H., Ramadan, Z. (2002). Understanding and controlling rotations in factor analytic models. Chemom. Intell. Lab. Syst. 60, 253-264. https://doi.org/10.1016/S01 69-7439(01)00200-3

Pakkanen, T.A., Kerminen, V.M., Loukkola, K., Hillamo, R.E., Aarnio, P., Koskentalo, T., Maenhaut, W. (2003). Size distributions of mass and chemical components in street-level and rooftop $\mathrm{PM}_{1}$ particles in Helsinki. Atmos. Environ. 37, 1673-1690. https://doi.org/10.1016/s13522310(03)00011-6

Pandolfi, M., Gonzalez-Castanedo, Y., Alastuey, A., de la Rosa, J.D., Mantilla, E., de la Campa, A.S., Querol, X., Pey, J., Amato, F., Moreno, T. (2011). Source apportionment of $\mathrm{PM}_{10}$ and $\mathrm{PM}_{2.5}$ at multiple sites in the strait of Gibraltar by PMF: Impact of shipping emissions. Environ. Sci. Pollut. Res. Int. 18, 260-269. https://doi.org/10.1007/s11356-010-0373-4

Pekney, N.J., Davidson, C.I. (2005). Determination of trace elements in ambient aerosol samples. Anal. Chim. Acta 540, 269-277. https://doi.org/10.1016/j.aca.2005.03.065

Petit, J.E., Favez, O., Sciare, J., Canonaco, F., Croteau, P., Močnik, G., Jayne, J., Worsnop, D., LeozGarziandia, E. (2014). Submicron aerosol source apportionment of wintertime pollution in Paris, France by double positive matrix factorization $\left(\mathrm{PMF}^{2}\right)$ using an aerosol chemical speciation monitor (ACSM) and a multi-wavelength Aethalometer. Atmos. Chem. Phys. 14, 13773-13787. https://doi.org/10.5194/acp-14-13773-2014

Rolph, G.D. (2015). Real-time Environmental Applications and Display sYstem (READY) Website. https://www.ready.noaa.gov/index.php (accessed 17 February 2021).

Saffari, A., Hasheminassab, S., Shafer, M.M., Schauer, J.J., Chatila, T.A., Sioutas, C. (2016). Nighttime aqueous-phase secondary organic aerosols in Los Angeles and its implication for fine particulate matter composition and oxidative potential. Atmos. Environ. 133, 112-122. https://doi.org/10.1016/j.atmosenv.2016.03.022

Skamarock, W.C., Klemp, J.B. (2008). A time-split nonhydrostatic atmospheric model for weather research and forecasting applications. J. Comput. Phys. 227, 3465-3485. https://doi.org/10.10 16/j.jcp.2007.01.037

Solomon, P.A., Sioutas, C. (2008). Continuous and semicontinuous monitoring techniques for particulate matter mass and chemical components: A synthesis of findings from EPA's Particulate Matter Supersites Program and related studies. J. Air Waste Manage. Assoc. 58, 164-195. https://doi.org/10.3155/1047-3289.58.2.164

Srivastava, D., Favez, O., Petit, J.E., Zhang, Y., Sofowote, U.M., Hopke, P.K., Bonnaire, N., Perraudin, E., Gros, V., Villenave, E., Albinet, A. (2019). Speciation of organic fractions does matter for 
aerosol source apportionment. Part 3: Combining off-line and on-line measurements. Sci. Total Environ. 690, 944-955. https://doi.org/10.1016/j.scitotenv.2019.06.378

Stein, A.F., Draxler, R.R., Rolph, G.D., Stunder, B.J.B., Cohen, M.D., Ngan, F. (2015). NOAA's HYSPLIT Atmospheric Transport and Dispersion Modeling System. Bull. Am. Meteorol. Soc. 96, 20592077. https://doi.org/10.1175/BAMS-D-14-00110.1

Streets, D.G., Gupta, S., Waldhoff, S.T., Wang, M.Q., Bond, T.C., Bo, Y.Y. (2001). Black carbon emissions in China. Atmos. Environ. 35, 4281-4296. https://doi.org/10.1016/s1352-2310(01)0 0179-0

Sun, Y.L., Zhuang, G.S., Ying, W., Han, L.H., Guo, J.H., Mo, D., Zhang, W.J., Wang, Z.F., Hao, Z.P. (2004). The air-borne particulate pollution in Beijing - concentration, composition, distribution and sources. Atmos. Environ. 38, 5991-6004. https://doi.org/10.1016/j.atmosenv.2004.07.009

Swietlicki, E., Krejci, R. (1996). Source characterisation of the Central European atmospheric aerosol using multivariate statistical methods. Nucl. Instrum. Methods Phys. Res., Sect. B 109, 519-525. https://doi.org/10.1016/0168-583x(95)01220-6

Tian, Y., Xiao, Z., Wang, H., Peng, X., Guan, L., Huangfu, Y., Shi, G., Chen, K., Bi, X., Feng, Y. (2017). Influence of the sampling period and time resolution on the PM source apportionment: Study based on the high time-resolution data and long-term daily data. Atmos. Environ. 165, 301309. https://doi.org/10.1016/j.atmosenv.2017.07.003

Tsai, D.H., Wang, J.L., Wang, C.H., Chan, C.C. (2008). A study of ground-level ozone pollution, ozone precursors and subtropical meteorological conditions in central Taiwan. J. Environ. Monit. 10, 109-118. https://doi.org/10.1039/b714479b

Tsai, J.H., Tsai, S.M., Wang, W.C., Chiang, H.L. (2016). Water-soluble ionic species of coarse and fine particulate matter and gas precursor characteristics at urban and rural sites of central Taiwan. Environ. Sci. Pollut. Res. 23, 16722-16737. https://doi.org/10.1007/s11356-016-6834-7

Turpin, B.J., Huntzicker, J.J. (1995). Identification of secondary organic aerosol episodes and quantitation of primary and secondary organic aerosol concentrations during SCAQS. Atmos. Environ. 29, 3527-3544. https://doi.org/10.1016/1352-2310(94)00276-Q

Upadhyay, N., Majestic, B.J., Prapaipong, P., Herckes, P. (2009). Evaluation of polyurethane foam, polypropylene, quartz fiber, and cellulose substrates for multi-element analysis of atmospheric particulate matter by ICP-MS. Anal. Bioanal. Chem. 394, 255-266. https://doi.org/10.1007/s0 0216-009-2671-6

Viana, M., Kuhlbusch, T.A.J., Querol, X., Alastuey, A., Harrison, R.M., Hopke, P.K., Winiwarter, W., Vallius, M., Szidat, S., Prévôt, A.S.H., Hueglin, C., Bloemen, H., Wåhlin, P., Vecchi, R., Miranda, A.I., Kasper-Giebl, A., Maenhaut, W., Hitzenberger, R. (2008). Source apportionment of particulate matter in Europe: A review of methods and results. J. Aerosol Sci. 39, 827-849. https://doi.org/10.1016/j.jaerosci.2008.05.007

Wang, Q.Q., Qiao, L.P., Zhou, M., Zhu, S.H., Griffith, S., Li, L., Yu, J.Z. (2018). Source apportionment of $\mathrm{PM}_{2.5}$ using hourly measurements of elemental tracers and major constituents in an urban environment: Investigation of time-resolution influence. J. Geophys. Res. 123, 5284-5300. https://doi.org/10.1029/2017jd027877

Watson, J.G., Chow, J.C., Lu, Z., Fujita, E.M., Lowenthal, D.H., Lawson, D.R., Ashbaugh, L.L. (1994). Chemical Mass Balance Source Apportionment of $\mathrm{PM}_{10}$ during the Southern California Air Quality Study. Aerosol Sci. Technol. 21, 1-36. https://doi.org/10.1080/02786829408959693

Wimolwattanapun, W., Hopke, P.K., Pongkiatkul, P. (2011). Source apportionment and potential source locations of $\mathrm{PM}_{2.5}$ and $\mathrm{PM}_{2.5-10}$ at residential sites in metropolitan Bangkok. Atmos. Pollut. Res. 2, 172-181. https://doi.org/10.5094/APR.2011.022

Wood, E.C., Canagaratna, M.R., Herndon, S.C., Onasch, T.B., Kolb, C.E., Worsnop, D.R., Kroll, J.H. Knighton, W.B., Seila, R., Zavala, M., Molina, L.T., DeCarlo, P.F., Jimenez, J.L., Weinheimer, A.J., Knapp, D.J., Jobson, B.T., Stutz, J., Kuster, W.C., Williams, E.J. (2010). Investigation of the correlation between odd oxygen and secondary organic aerosol in Mexico City and Houston. Atmos. Chem. Phys. 10, 8947-8968. https://doi.org/10.5194/acp-10-8947-2010

Wu, C., Yu, J.Z. (2016). Determination of primary combustion source organic carbon-to-elemental carbon (OC/EC) ratio using ambient OC and EC measurements: Secondary OC-EC correlation minimization method. Atmos. Chem. Phys. 16, 5453-5465. https://doi.org/10.5194/acp-165453-2016

Yang, H.H., Tsai, C.H., Chao, M.R., Su, Y.L., Chien, S.M. (2006). Source identification and size 
distribution of atmospheric polycyclic aromatic hydrocarbons during rice straw burning period. Atmos. Environ. 40, 1266-1274. https://doi.org/10.1016/j.atmosenv.2005.10.032

Zhou, L., Hopke, P.K., Zhao, W. (2009). Source apportionment of airborne particulate matter for the speciation trends network site in Cleveland, OH. J. Air Waste Manage. Assoc. 59, 321-331. https://doi.org/10.3155/1047-3289.59.3.321

Zhu, Y., Huang, L., Li, J., Ying, Q., Zhang, H., Liu, X., Liao, H., Li, N., Liu, Z., Mao, Y., Fang, H., Hu, J. (2018). Sources of particulate matter in China: Insights from source apportionment studies published in 1987-2017. Environ. Int. 115, 343-357. https://doi.org/10.1016/j.envint.2018.03.037 